\title{
Peningkatan Kualitas Pembelajaran Melalui Alat Permainan Edukatif (APE) Dan Sosialisasi Keselamatan Bermain Outdoor Bagi Paud Bina Cendikia Desa Sidorejo Kabupaten Malang
}

\author{
Muhammad Akhlis Rizza ${ }^{1}$, Ratna Monasari ${ }^{*}$, Etik Puspitasari ${ }^{3}$, Kris Witono ${ }^{4}$ \\ ${ }^{1234}$ Teknik Mesin, Politeknik Negeri Malang, Indonesia, 65145
}

E-mail:* rmonasari@polinema.ac.id

Doi : https://doi.org/10.37339/jurpikat.v2i3.681

Info Artikel:

Diterima :

2021-08-29

Diperbaiki :

2021-11-22

Disetujui :

2021-11-22

Kata Kunci: Alat permainan edukatif, Permainan outdoor, Stimulasi anak, Program pendidikan anak usia dini
Abstrak: Abstrak: Salah satu media pembelajaran utama yang digunakan dalam sistem pendidikan anak usia dini ialah Alat Permainan Edukatif (APE). APE akan menunjang keberhasilan proses belajar melalui pengembangan aspek motorik halus dan kasar yang dilakukan pada area bermain indoor maupun outdoor. APE indoor dapat dipenuhi melalui pembuatan sendiri dari bahan yang tersedia di sekitar, sedangkan APE outdoor sebagian besar membutuhkan alat bantu pabrikasi yang harganya relatif mahal. Tujuan utama penyediaan APE outdoor adalah untuk meningkatkan kreativitas, keterampilan fisik, rasa percaya diri, daya nalar, kemampuan bersosialisasi dan meningkatkan motivasi belajar siswa. Ketersediaan APE outdoor pada PAUD Bina Cendikia Malang masih sangat terbatas sehingga program kegiatan belajar untuk mengembangkan aspek motorik siswa kurang optimal. Selain itu diperlukan peningkatan pemahaman tentang keselematan bermain bagi anak agar guru dan wali siswa dapat memastikan kegiatan bermain berlangsung dengan aman, menarik, menyenangkan, dan minim resiko. Hasil kegiatan pengabdian pada masyarakat pada PAUD Bina Cendikia dapat meningkatkan kualitas pembelajaran.

Abstract: One of the main learning media used in the early childhood education system is the Educational Game Tool. Educational Game Tool will support the success of the learning process through the development of fine and gross motor aspects carried out in indoor and outdoor play areas. Educational game tool for indoor can be fulfilled by making your own from 
Keywords: Educational game tools, Outdoor games, Children's stimulation, Early childhood education program materials available around, while outdoor educational game tool mostly requires manufacturing tools that are relatively expensive. The main purpose of providing outdoor APE is to increase creativity, physical skills, self-confidence, reasoning power, social skills, and increase student learning motivation. The availability of outdoor APE at PAUD Bina Cendikia Malang is still very limited so that the learning activity program to develop students' motor aspects is not optimal. In addition, it is necessary to increase understanding of the safety of playing for children so that teachers and guardians of students can ensure that playing activities take place safely, interestingly, fun, and with minimal risk. The results of community service activities at PAUD Bina Cendikia can improve the quality of learning.

\section{Pendahuluan}

Anak usia dini secara umum didefinisikan anak - anak yang memiliki usia di bawah 6 tahun. Sementara itu UU Sisdiknas mendefinisikan anak usia dini merupakan anak dengan rentang usia $0-6$ tahun. Sementara itu berdasarkan pada artikel yang ditulis Dwi Yulianti, menurut Beichler dan Snowman anak usia dini memili rentang usia 3 - 6 tahun (Dwi Yulianti, 2010), sedangkan pengertian anak usia dini menurut Augusta merupakan individu yang sedang dalam masa bertumbuh dan berkembang melalui aspek fisik, kognitif, kreativitas, dan komunikasi sesuai dengan tahap usia anak.

Perkembangan anak terjadi sangat pesat pada usia keemasan atau yang sering dikenal dengan golden age. Di masa ini anak memiliki potensi besar dalam dirinya untuk dikembangkan, namun sering kali anak belum mampun untuk mengenali dan mengembangkannya sendiri tanpa bantuan dari orang dewasa. Anak lebih senang bermain dan melakukan kegiatan yang berhubungan dengan fisik. Anak juga cenderung melakukan sesuatu seenaknya dan ingin menang sendiri. Dengan begitu perlu adanya upaya untuk mengoptimalisasi semua aspek dalam perkembangan anak, baik dari sisi perkembangan secara fisik maupun secara emosional. Potensi anak pada usia keemasan ini sangat penting untuk distimulasi agar berkembang dengan baik. Beberapa aspek yang perlu dikembangkan pada anak usia dini yaitu kemampuan fisik, kognitif, sosial emosional, bahasa dan aspek lainnya.

Salah satu perkembangan anak yang perlu diperhatikan yaitu fisik motorik. Tujuan pengembangan aspek motorik ini untuk membantu meningkatkan keterampilan anak secara fisik dalam melatih gerakan motorik halus dan kasar. Selain itu untuk meningkatkan kemampuan dalam mengontrol dan mengelola gerak dari anggota tubuh dimana semua itu dibutuhkan untuk menunjang tumbuh kembang anak yang sehat, kuat, dan terampil secara jasmani. Untuk itu perlu 
diberikan stimulasi yang tepat sesuai dengan tahapan usianya (Bambang Sujiono, 2010).

Definisi dari motorik kasar yaitu gerakan tubuh yang dilakukan dengan menggunakan otot - otot besar dari anggota tubuh yang dipengaruhi oleh kemampuan seseorang berdasakan usia, misalnya kemampuan untuk berjalan, berlari, menendang, melompat dan lain sebagainya. Sedangkan pengertian dari sistem motorik halus ialah gerakan yang dilakukan seseorang menggunakan sebagian kecil otot dari anggota tubuh tertentu. Motorik halus dipengaruhi dari hasil belajar dan berlatih, misalnya untuk menulis, menggunting, mengankat sebuah benda menggunakan tangan, dan menyusun. Kedua kemampuan motorik ini sangat penting untuk selalu dilatih agar tumbuh kembangnya berjalan dengan baik.

Pada anak usia dini salah satu cara yang dapat dilakukan untuk melatih sistem motoriknya adalah dengan bermain, permainan untuk melatih motorik tidak hanya dilakukan di dalam ruangan namun juga dapat dilakukan di luar ruangan. Kedia hal ini sangat penting untuk memberikan stimulasi terhadap anak usia dini lewat perkembangan motoriknya. Permainan di luar ruangan atau outdoor yang dilakukan oleh anak dapat mengembangkan kemampuan anak ketika mereka melakukan aktivitas fisik. Selain itu kebiasaan yang sering dilakukan orang tua justru membatasi anak untuk bermain pada area outdoor karena beberapa faktor. Umumnya kesibukan orang tua sehingga pengawasan terhadap anak berkurang dan faktor lingkungan dirasa tidak aman menjadi faktor utama orang tua mengganti permainan outdoor menjadi tontonan melalui gawai.

Dalam penataan lingkungan bermain outdoor bagi anak hal penting yang perlu diperhatikan adalah ketika anak mendapatkan pengalaman unik, dapat bereksplorasi dan mengobservasi keadaan sekitar area bermain dengan panca inderanya sendiri. Contohnya anak dapat memegang permukaan sekitarnya, melihat perubahan warna, mendengar suara hewan, dan mencium aroma bunga yang terdapat di sekitar lingkungan. Anak belajar untuk menggunakan semua indra perasa mereka untuk bertumbuh dan berkembang serta belajar mengenai dunia sekitarnya. Oleh karena itu penting untuk melakukan perancangan dan penataan lingkungan bermain anak yang yang tepat sehingga dapat mendukung tumbuh kembang anak.

Alat permainan edukatif menurut depdiknas adalah segala sesuatu yang tersedia disekitar kita yang bisa dimanfaatkan sebagai alat ataupun sarana bermain anak. Alat permainan edukatif harus mengandung nilai pendidikan bagi anak sebagai penggunanya dan dapat mengembangkan kemampuan anak. Hal serupa juga tertulis pada artikel yang ditulis oleh Andang Ismail, untuk meningkatkan fungsi sosioemosional, kognitif, dan spiritual anak dapat dikembangkan dengan alat permainan edukatif. Dengan alat permainan edukatif anak mampu mengembangkan seluruh potensi dalam dirinya membentuk kecerdasan pada anak. 
Alat permainan edukatif sendiri selain digunakan oleh anak, juga dapat dimanfaatkan oleh guru dan orang tua untuk menjalin kedekatan serta penunjang proses pembelajaran (Andang Ismail, 2009).

Untuk menjadi sebuah alat permainan edukatif tentunya memiliki syarat sebagai berikut: memiliki nilai pendidikan, aman digunakan bagi anak sesuai dengan usianya, memiliki bentuk maupun watna yang menarik minat anak, sederhana, awet, dan memiliki ukuran yang sesuai dengan usia anak. Sementara itu fungsi dari alat permainan edukatif itu sendiri dapat merangsang perkembangan saya pikir anak, menguatkan cipta dan bahasa pada anak, dan memberikan ilmu pengetahuan kepada anak melalui proses bermain. Alat permaian edukatif juga dapat menciptakan lingkungan bermain bagi anak - anak dengan memberikan rasa aman, menarik, dan menyenangkan untuk meningkatkan kualitas belajar bagi anak. (Andang Ismail, 2019)

PAUD Bina Cendikia Desa Sidorejo berdiri sejak tahun 2005 atas inisiatif dan swadaya masyarakat sendiri. Masih banyaknya anak yang tidak mengenyam pendidikan usia dini di Desa Sidorejo dikarenakan kurangnya kesadaran akan pentingnya pendidikan non formal dan utamanya karena keterbatasan kemampuan finansial, sehingga banyak orang tua yang langsung menyekolahkan anaknya pada jenjang sekolah dasar. Hal ini tentu menyulitkan pihak sekolah dan anak itu sendiri karena kesiapan anak untuk menjalani pendidikan formal masih sangat minim. Anak juga kehilangan sebagian besar masa emas (golden age) perkembangan otaknya tanpa mendapatkan stimulasi yang optimal. Untuk itu, keberadaan PAUD Bina Cendikia dimaksudkan untuk menyediakan sarana belajar anak usia dini yang terjangkau namun tidak mengurangi kualitas pembelajaran.

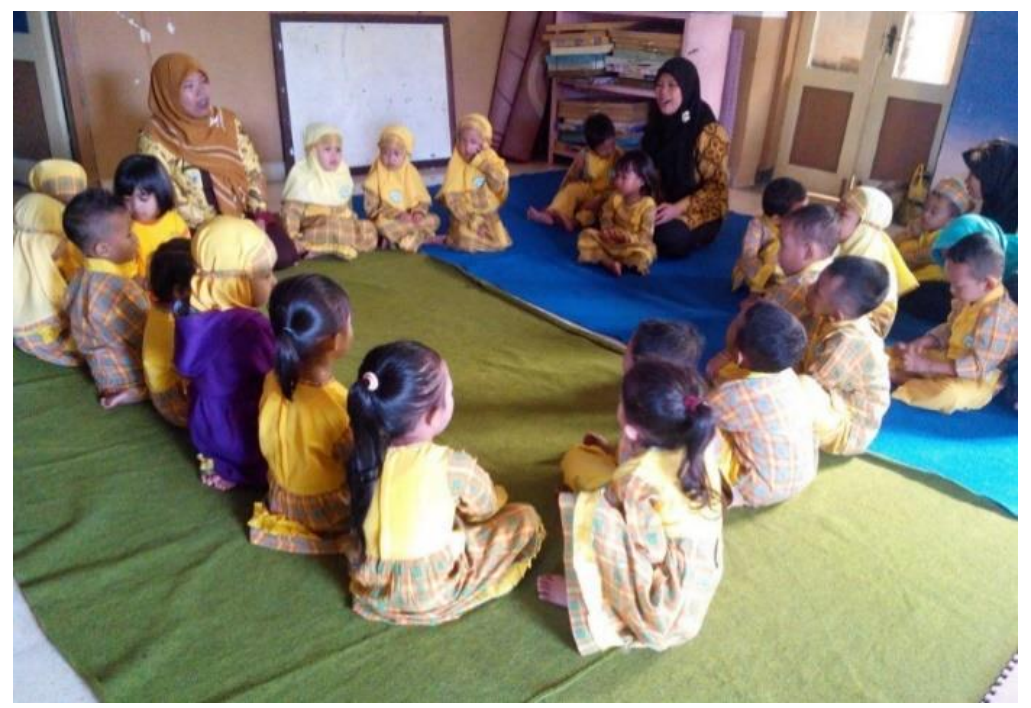

Gambar 1. Suasana Belajar PAUD Bina Cendikia

Sebagaimana yang diketahui mengenai konsep pembelajaran anak usia dini, alat bermain yang edukatif sangat penting dalam mendukung keberhasilan program 
belajar. Pada anak usia dini perlu diberikan stimulasi dari kegiatan - kegiatan yang dapat merangsang kemampuan dasar yang dimiliki anak untuk dapat bertumbuh dan berkembang secara optimal. Bentuk stimulasi yang diberikan bermacam macam, salah satunya melalui pembelajaran dengan bermain menggunakan alat permainan edukatif. Alat permainan edukatif sendiri terdiri dari dua kategori yaitu alat permainan dalam ruangan dan luar ruangan. Keragaman alat permainan edukatif dapat disesuaikan dengan tema atau materi yang diberikan untuk masing masing klasifikasi kelas berdasarkan usia anak.

Dengan semakin berkembangnya dunia pendidikan dan daya pikir anak, maka ketersediaan sarana prasarana atau media pembelajaran berupa alat permainan edukatif juga harus terpenuhi dalam upaya meningkatkan layanan pembelajaran yang lebih berkualitas di PAUD Bina Cendikia. Tentunya, dalam penggunaan alat permainan edukatif (APE) outdoor ini dibutuhkan panduan keselamatan bermain yang meliputi penataan lingkungan tempat bermain, cara penggunaan APE yang aman dan pengurangan resiko kecelakaan. Mengingat anak usia dini masih memerlukan dampingan guru dan orang tua dalam bermain, maka, diperlukan juga sosialisasi bagi guru dan wali siswa tentang keselamatan bermain outdoor yang aman dan minim resiko sehingga penerapannya tidak hanya untuk kepentingan selama belajar di sekolah tetapi juga dalam kegiatan bermain dirumah.

\section{Metode}

Kegiatan PPM dilaksanakan di PAUD Bina Cendikia Desa Sidorejo Kecamatan Jabung Kabupaten Malang. Mitra binaan ini masih sangat membutuhkan ketersediaan Alat Permainan Edukatif (APE) yang bervariasi khususnya untuk kegiatan di luar kelas (outdoor). Alat permainan edukatif dirancang sesuai dengan kebutuhan anak untuk dapat digunakan dalam bermain dan belajar sehingga terjadi peningkatan dalam aspek perkembangan anak. Anak usia dini akan merasa lebih nyaman dan antusias apabila pembelajaran diikuti dengan gerakan dan permainan. PAUD Bina Cendikia membutuhkan adanya alat permainan edukatif yang menunjang kegiatan belajar mengajar khususnya di luar ruangan sekaligus juga bagi guru dan wali siswa membutuhkan pengetahuan dan pemahaman mengenai aspek - aspek keselamatan bermain outdoor untuk anak usia dini. Dengan demikian akan menciptakan suasana belajar dan lingkungan bermain yang menarik, menyenangkan, memberikan rasa aman, serta meningkatkan motivasi belajar yang tentunya secara keseluruhan akan sangat berpengaruh terhadap hasil dan pencapaian tujuan belajar yang optimal.

Kegiatan PPM yang ditawarkan untuk menyelesaikan permasalahan pada PAUD Bina Cendikia sebagai mitra yaitu dengan menyediakan Alat Permainan Edukatif (APE) outdoor sesuai kebutuhan materi pembelajaran serta sosialisasi keselamatan bermain outdoor bagi guru dan wali siswa PAUD Bina Cendikia yang 
akan dilaksanakan langsung di sekolah dalam bentuk ceramah dan juga simulasi/praktek di halaman sekolah. Kegiatan PPM ini meliputi beberapa tahapan utama diantaranya:

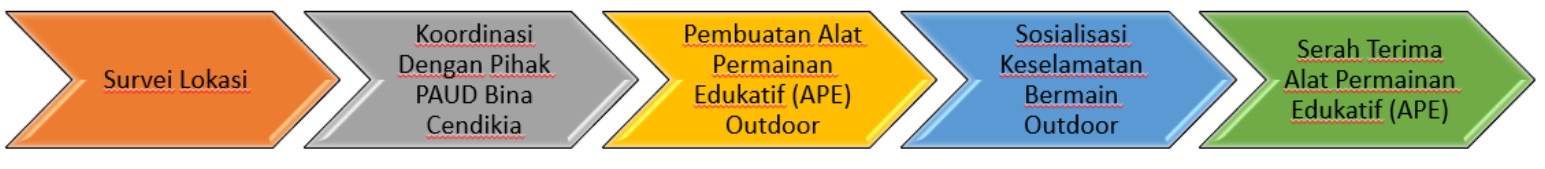

Gambar 2. Flowchart Kegiatan PPM

1. Survei lokasi

Survei lokas dilakukan untuk mengetahui kondisi dan fasilitas Alat Permainan Edukatif (APE) yang tersedia di PAUD Bina Cendikia. Hanya terdapat 2 APE yang berada di lingkungan outdoor PAUD Bina Cendikia.

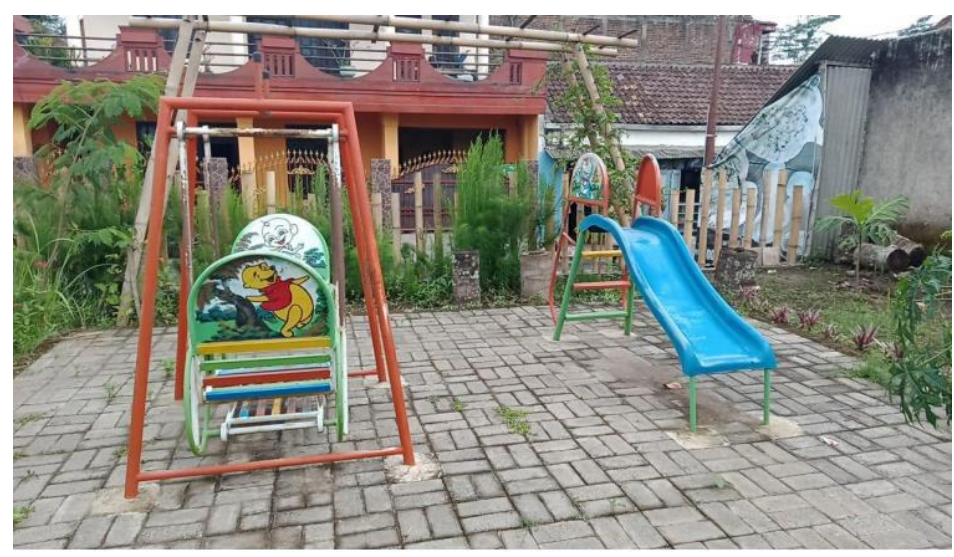

Gambar 3. Kondisi Area Permainan Outdoor PAUD Bina Cendikia

2. Koordinasi dengan pihak PAUD Bina Cendikia

Pada tahap ini dilakukan diskusi dengan pihak sekolah baik guru maupun kepala sekolah terkait metode pembelajaran yang meningkatkan motorik siswa PAUD Bina Cendikia. Sekaligus mendiskusikan masalah yang terjadi dengan keterbatasan Alat Permainan Edukatif (APE) di sekolah.

3. Pembuatan Alat Permainan Edukatif (APE) outdoor

Tahap ini dilakukan dengan pembuatan berupa tambahan 2 Alat Permainan Edukatif (APE). Dalam pembuatannya perlu dipertimbangkan aspek keselamatan, kesehatan, dan keamanan anak pada saat digunakan. Alat permainan edukatif ditempatkan secara permanen pada lokasi permainan outdoor PAUD Bina Cendikia.

4. Sosialisasi keselamatan bermain outdoor bagi guru dan wali siswa 
Tahap selanjutnya merupakan sosialiasasi dengan tema keselamatan bermain outdoor. Pada tahap ini guru dan wali siswa diberikan pelatihan singkat mengenai hal - hal yang perlu diperhatikan ketika mengawasi siswa/anak ketika mereka bermain outdoor.

5. Serah terima Alat Permainan Edukatif (APE)

Setelah semua tahap di atas selesai maka dilakukan evaluasi secara singkat mengenai dampak dengan penambahan Alat Permainan Edukatif (APE) yang diberikan. Selanjutnya dilakukan serah terima secara resmi oleh tim PPM Politeknik Negeri Malang kepada kepala sekolah dan guru PAUD Bina Cendikia.

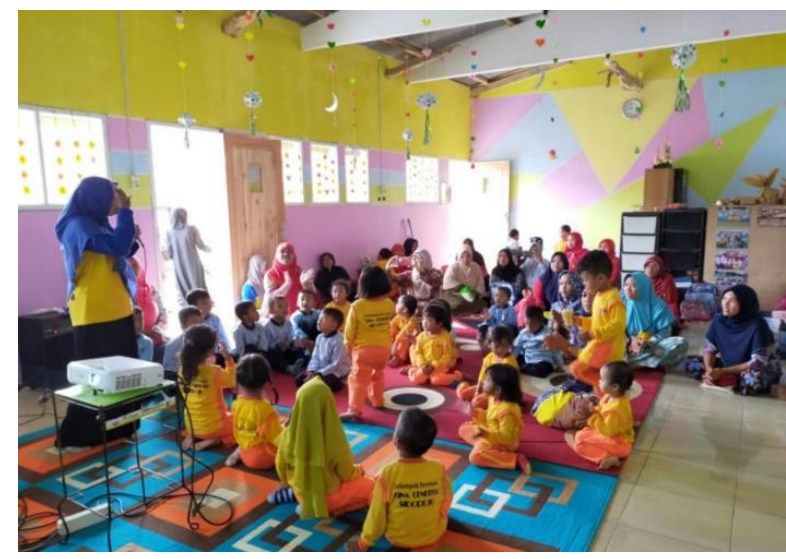

Gambar 4. Sosialisasi Keselamatan Bermain Outdoor

Yang menjadi subjek dari kegiatan pengabdian pada masyarakat (PPM) ini adalah 3 orang guru, 25 wali murid dan 25 murid dari PAUD Bina Cendikia. Pelaksanaan kegiatan PPM berlangsung di PAUD Bina Cendikia Desa Sidorejo, Kecamatan Jabung Kabupaten Malang. Waktu Pelaksanaan pada bulan Juli sampai Agustus 2021.

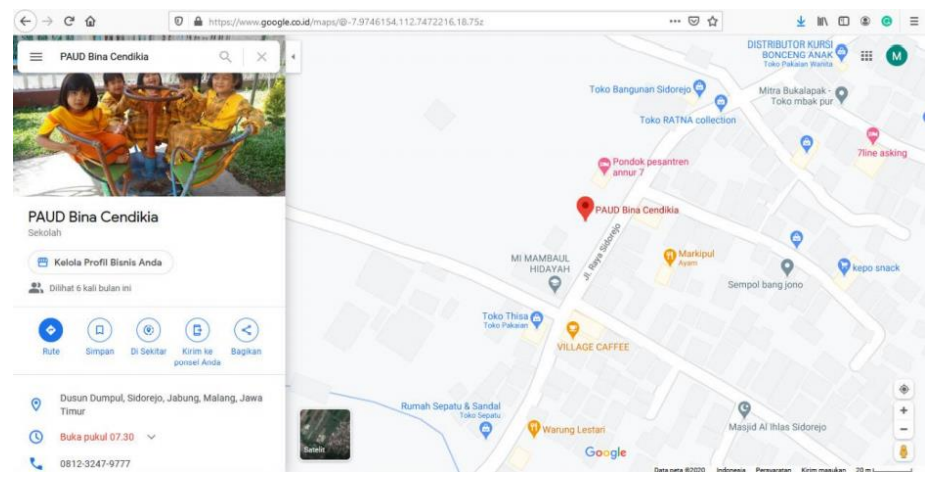

Gambar 5. Lokasi PAUD Bina Cendikia Desa Sidorejo, Kecamatan Jabung Kabupaten Malang 


\section{Hasil dan Pembahasan}

Pada kegiatan PPM yang telah terlaksana ini memperoleh hasil bahwa Alat Permainan Edukatif (APE) outdoor sangat diperlukan untuk melatih motorik siswa, dengan pengadaan dan pemberian APE pada area bermain PAUD Bina Cendikia semakin meningkatkan kualitas pembelajaran bagi siswa. Siswa terlatih secara motorik sehingga keterampilan gerak, keseimbangan, dan juga koordinasi antar anggota tubuh dapat terlatih dengan baik. Selain itu dengan adanya tambahan variasi alat permainan edukatif pada PAUD Bina Cendikia dapat menanamkan rasa percaya diri, perilaku disiplin, jujur, dan sportif serta sikap mampu bekerja sama.

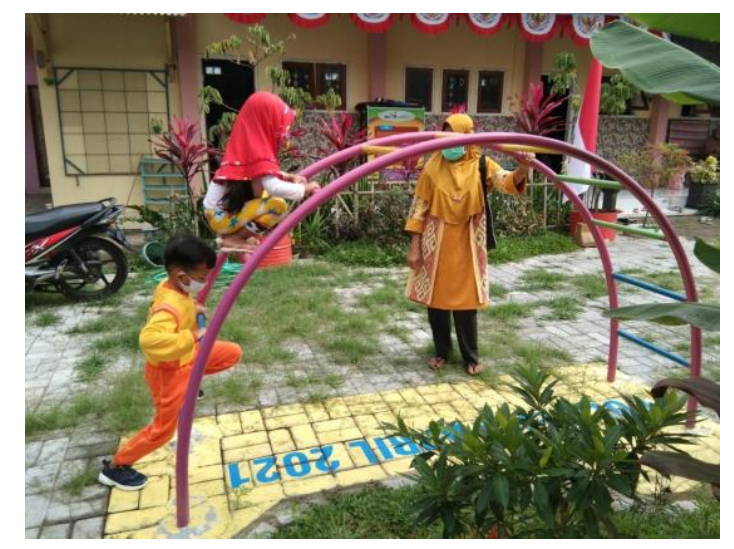

Gambar 6. Alat Permainan Edukatif (APE) jenis tangga jembatan lengkung

Gambar 6 menunjukkan salah satu jenis APE outdoor jenis tangga. Alat permainan ini dapat mengembangkan kekuatan otot tangan dan kaki. Dengan APE jenis tangga anak juga terlatih untuk mengkoordinasi antara penglihatan, gerakan tangan dan kaki pada saat menaiki atau menuruni anak tangga. Alat permainan edukatif tangga sangat bervariasi jenisnya. Ada yang berupa tangga biasa, menyerupai bentuk bola, bentuk kubus atau yang biasa dikenal sebagai tangga majemuk, serta jembatan lengkung seperti yang tim PPM Polinema berikan pada PAUD Bina Cendikia.

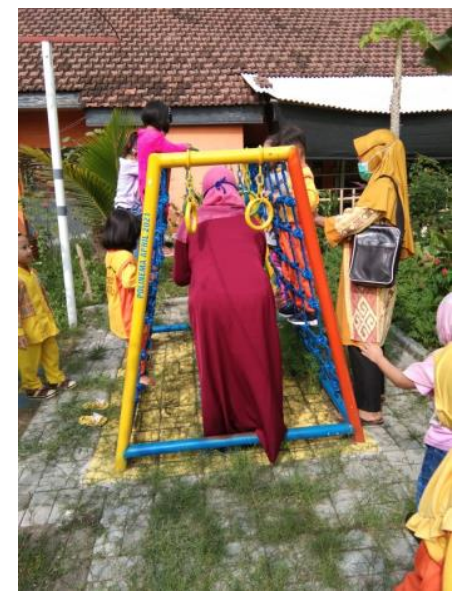

Gambar 7. Alat Permainan Edukatif (APE) jenis tangga kubus 
Kegiatan ini telah dilaksanakan dengan melibatkan kepala sekolah, guru, dan wali murid PAUD Bina Cendikia Desa Sidorejo, Kecamatan Jabung Kabupaten Malang sebagai mitra pengabdian. Respon yang diberikan oleh guru maupun wali murid sangat baik akan program pengadaan alat permainan edukatif ini, karena APE yang tersedia di PAUD Bina Cendikia sangat terbatas sehingga sering kali terjadi perkelahian siswa yang ingin bermain.

Terdapat 2 buah Alat Permainan Edukatif (APE) outdoor yang disediakan oleh tim PPM Politeknik Negeri Malang dengan jenis tangga kubus dengan tali dan jembatan lengkung seperti pada gambar 6 dan gambar 7 .

Sementara itu kegiatan sosialisasi mengenai keselamatan bermain outdoor dilaksanakan pada tanggal 16 Agustus 2021. Peserta pada kegiatan ini kepala sekolah, guru, dan wali siswa. Sosialisasi menekankan beberapa aspek diantaranya fungsi mainan, usia anak, kemampuan, minat anak dan keamanan berdasarkan bentuk, ukuran dan material. Alat permainan hendaknya dipergunakan sesuai dengan tahapan usia anak. Pada pelaksanaannya guru dan wali siswa masih memiliki pengetahuan yang terbayas tentang keamanan alat bermain outdoor.

Analisis mengenai tempat bermain yang aman meliputi: (1) Kondisi tempat bermain terdapat penghalang atau tidak sehingga guru dapat mengawasi setiap saat. (2) Daerah bermain dan permainan dapat dilakukan sendiri maupun berkelompok. (3) Alat permainan yang aman. (4) Terdapat lubang air, kabel listrik, atau peralatan berbahaya lainnya. (5) Ketersediaan peralatan P3K.

Sarana bermain yang mengutamakan perkembangan motorik kasar tentu harus dirancang sedemikian aman, sehingga pada saat digunakan tidak membahayakan bagi anak. Kegiatan bermain outdoor bukan semata agar anak dapat melepaskan energinya, namun kegiatan bermain outdoor ini dirancang agar anak dapat melakukan kegiatan yang berperan bagi pertumbuhan dan perkembangan sesuai dengan usianya. Oleh karena hal tersebut guru harus mengawasi keamanan pada saat bermain. Selain itu guru juga harus memonitor keamanan area bermain siswa agar setiap anak dapat bermain dengan aman dan nyaman serta terhindat dari kecelakaan di area bermain.

Selanjutnya kegiatan serah terima Alat Permainan Edukatif (APE) dari tim PPM Politeknik Negeri Malang kepada PAUD Bina Cendikia dilaksanakan pada 18 Agustus 2021 secara langsung dengan menerapkan protokol kesehatan.

Kegiatan PPM ini memberikan manfaat kepada mitra dengan bertambahnya alat permainan edukatif yang sangat penting sebagai alat bantu pembelajaran siswa sehingga kegiatan bermain siswa PAUD lebih bervariasi dan membuat siswa tidak mengantri terlalu lama untuk bergantian bermain. Selain itu dengan diberikannya sosialisasi kepada guru dan wali siswa mengenai keselamatan bermain outdoor 
dapat meningkatkan kepedulian akan pengawasan guru dan wali siswa saat bermain pada area outdoor dimanapun anak bermain.

\section{Kesimpulan}

Kesimpulan yang diperoleh dari kegiatan Pengabdian Pada Masyarakat (PPM) penyediaan Alat Permainan Edukatif (APE) bagi PAUD Bina Cendikia Desa Sidorejo, Kecamatan Jabung Kabupaten Malang berlangsung dengan baik dan memberikan manfaat bagi guru maupun siswa. Dengan diberikannya dua APE menjadikan area bermain outdoor PAUD Bina Cendikia lebih bervariatif dengan alat permainan edukatif, sehingga siswa dapat lebih belajar mengembangkan motorik pada usia keemasannya. Selain itu dengan kegiatan sosialisasi bermain outdoor guru dan wali murid dapat lebih memahami faktor keselamatan saat anak bermain dan bagaimana pencegahan kecelakaan saat anak bermain di luar ruangan. Saran untuk kedepannya kerjasama dengan mitra dapat dilanjutkan dengan program program lain mengingat mitra masih sangat membutuhkan dukungan untuk mengembangkan sistem pendidikan.

\section{Ucapan Terima Kasih}

Terima kasih kami sampaikan kepada UPT Penelitian dan Pengabdian Masyarakat Politeknik Negeri Malang yang telah membiayai Pengabdian Pada Masyarakat ini dengan dana DIPA No: 023.18.2.6777606/2021.

\section{Referensi}

Bredekamp. (1987). Developmentally Appropriate Practice in Early Childhood Programs Serving Children from Birth Through Age 8. NY: AAEYC.

Yulianti, D. (2010). Bermain sambil Belajar Sains di Taman Kanakkanak. Jakarta: PT Indeks.

Yulisetyaningrum, Y. (2019). Perkembangan Sosial Emosional Anak Usia Pra Sekolah. Jurnal Ilmu Keperawatan Dan Kebidanan, 10(1), 221-228.

Patmonodewo, S. 2003. Pendidikan Anak Prasekolah. Jakarta: PT. Asdi Mahasatya. Badan Standarisasi Nasional (BSN), 2012. Standar Keamanan Mainan Anak. Jakarta. 
Kementerian Pendidikan dan Kebudayaan. Direktorat Pembinaan Pendidikan Anak Usia Dini, 2015, Pedoman Sarana Bermain Luar Ruangan (Outdoor), Jakarta.

Andang Ismail, Education Games (Menjadi Cerdas dan Ceria dengan Permainan Edukatif), Yogyakarta: Pilar Media, 2006.

Dadan Suryana, Pendidikan Anak Usia Dini: Stimulasi dan Aspek Perkembangan Anak, Jakarta: Kencana, 2016.

Hasanah Uswatun. 2019. “Penggunaan Alat Permainan Edukatif (APE) Pada Taman Kanak-Kanak Se-Kota Metro" AWLADY: Jurnal Pendidikan Anak Vol 5: 20.

Susilowati Retno. 2014. "Strategi Belajar Out Door Bagi Anak PAUD" Jurnal iainkudus Vol. 2 No. 1: 65-82.

Shofyatun A. Rahman, Alat Permainan Edukatif Untuk Program PAUD, Palu: Tadulako University Press, 2010.

Yuliani Nurani Sujiono, Konsep Dasar Pendidikan Anak Usia Dini, Jakarta: PT Indeks, 2012. 